\title{
Analisis Kemampuan Pemecahan Masalah Pada Materi Fungsi Melalui Penerapan Model Pendidikan Matematika Realistik
}

\author{
Dorothea Novia Ludo Lubur \\ Fakultas Keguruan dan Ilmu Pendidikan, Universitas Sanata Dharma Mrican Tromolpos 29 \\ Yogyakarta 55022, Indonesia \\ E-mail:novilubur@gmail.com
}

\begin{abstract}
Title (Analysis of Problem Solving Ability in Function Materials through the Application of the Realistic Mathematics Education Model). This study aims to determine the problem solving skills of IX grade students of SMPK St. Paulus on the material functions with the Realistic Mathematics Education approach. The method used in this research is descriptive qualitative. The subjects in this study consisted of 10 students of class IX. Students' answers are analyzed and classified according to the type of answer. The following student answers consist of 5 different types of answers. Seven students with the first, second and fourth types of answers fulfill four indicators. One student with the third type of answer only reaches two indicators namely the first and second indicators, and one student with the fifth answer type fulfills three indicators namely the first, third and fourth indicators. Based on the results of the analysis it can be concluded that there are $80 \%$ of students fulfilling the four indicators of NCTM, $10 \%$ of students do not meet the third and fourth indicators and $10 \%$ of students do not meet the second indicator.
\end{abstract}

Keywords: Problem solving skill; NCTM indicator; Realistic Mathematics Education approach.

Abstrak . Penelitian ini bertujuan untuk mengetahui kemampuan pemecahan masalah siswa kelas IX SMPK St. Paulus pada materi fungsi dengan menggunakan pendekatan Pendidikan Matematika Realistik. Metode yang digunakan dalam penelitian ini adalah deskriptif kualitatif. Subjek dalam penelitian ini terdiri dari 10 orang siswa kelas IX. Jawaban siswa dianalisis dan digolongkan berdasarkan jenis jawaban. Jawaban siswa tersebut terdiri dari 5 jenis jawaban yang berbeda. Tujuh siswa dengan jenis jawaban yang pertama, kedua dan keempat memenuh empat indikator. Satu siswa dengan jenis jawaban yang ketiga hanya mencapai dua indikator yaitu indikator pertama dan kedua, dan satu siswa dengan jenis jawaban yang kelima memenuhi tiga indikator yaitu indikator yang pertama, ketiga dan keempat. Berdasarkan hasil analisis tersebut dapat disimpulkan bahwa terdapat $80 \%$ siswa memenuhi keempat indikator dari NCTM, 10\% siswa tidak memenuhi indikator ketiga dan keempat dan 10\% siswa tidak memenuhi indikator kedua.

Kata Kunci: Kemampuan Pemecahan Masalah; Indikator NCTM; pendekatan PMR.

\section{PENDAHULUAN}

Matematika merupakan ilmu universal yang mendasari perkembangan teknologi modern, mempunyai peran penting dalam berbagai disiplin dan memajukan daya pikir manusia (Ibrahim dan Suparni, 2009: 35). Dalam mempelajari matematika ada beberapa kemampuan yang harus dimiliki siswa, salah satunya yaitu kemampuan pemecahan masalah. Kemampuan pemecahan masalah matematika sangat penting bagi siswa. Pentingnya pemecahan masalah matematika ditegaskan dalam NCTM (2000: 52) yang menyatakan bahwa pemecahan masalah merupakan bagian integral dalam pembelajaran matematika, sehingga hal tersebut tidak boleh dilepaskan dari pembelajaran matematika. Selain itu, kemampuan pemecahan masalah merupakan tujuan dari pembelajaran matematika.

Dalam mempelajari matematika ada beberapa kemampuan yang harus dimiliki siswa. National Council of Teachers of Mathematics (NCTM) menetapkan bahwa untuk mencapai standar isi, siswa harus memiliki lima kemampuan utama dalam matematika yaitu kemampuan pemecahan masalah, penalaran, komunikasi, penelusuran pola atau hubungan, dan representasi (NCTM, 2000).

Polya (Suherman 2003) berpendapat bahwa terdapat empat fase utama dalam pemecahan masalah yaitu: (1) memahami masalah, yaitu kita harus mampu melihat dan memahami apa saja yang dibutuhkan, (2) merencanakan strategi penyelesaian, yaitu kita 
harus mampu melihat hubungan berbagai data dan bagaimana hal-hal yang tak diketahui berhubungan dengan data kemudian merencanakan penyelesaiannya, (3) menerapkan strategi penyelesaian, yaitu melaksanakan rencana yang telah disusun, dan (4) memeriksa kembali hasil, yaitu melakukan pengecekan kembali terhadap hasil yang diperoleh.

Kemampuan pemecahan masalah matematis dapat diukur menggunakan beberapa indikator yaitu menurut NCTM (2000) : 1) Siswa dapat mengidentifikasi unsur-unsur yang diketahui, yang ditanyakan, dan kecukupan unsur yang diperlukan, 2) Siswa dapat merumuskan masalah matematik atau menyusun model matematik, 3) Siswa dapat menerapkan strategi untuk menyelesaikan berbagai masalah (sejenis dan masalah baru) dalam atau diluar matematika, 4) Siswa dapat menjelaskan hasil sesuai permasalahan asal, dan 5) Siswa dapat menggunakan matematika secara bermakna.

Pemecahan masalah merupakan bagian dari kurikulum matematika yang sangat penting. Hal ini dikarenakan siswa akan memperoleh pengalaman dalam menggunakan pengetahuan serta keterampilan yang dimiliki untuk menyelesaikan soal yang tidak rutin. Menurut Lencher sebagaiman dikutip dalam Yusuf Hartono pemecahan masalah matematika merupakan proses menerapkan pengetahuan matematika yang telah diperoleh sebelumnya ke dalam situasi baru yang belum dikenal. Sebagai implikasinya, aktivitas pemecahan masalah dapat menunjang perkembangan kemampuan matematika yang lain sepertikomunikasi dan penalaran matematika.

Pernyataan di atas sejalan dengan pendapat Ahmad Susanto yang menyatakan bahwa pemecahan masalah merupakan proses menerapkan pengetauan (knowledge) yang telah diperoleh siswa sebelumnya ke dalam situasi yang baru. Pemecahan masalah juga merupakan aktivitas yang sangat penting dalam pembelajaran matematika, karena tujan belajar yang ingin dicapai dalam pemecahan masalah berkaitan dengan kehidupan sehari-hari.

Menurut Hudojo sebagaimana dikutip Nyimas Aisyah dalam bukunya, pemecahan masalah pada dasarnya adalah proses yang ditempuh oleh seseorang untuk menyelesaikan masalah yang dihadapinya sampai masalah itu tidak lagi menjadi masalah baginya. Hal ini berkaitan dengan pendapat Robert L.Solso dan Otto H. Maclin yang mengatakan bahwa pemecahan masalah adalah suatu pemikiran yang terarah secara langsung untuk menemukan suatu solusi/jalan keluar untuk suatu masalah yang spesifik. Solso mengemukakan enam tahapan dalam pemecahan masalah, yaitu: (1) Identifikasi permasalahan, (2) Representasi permasalahan, (3) Perencanaan pemecahan,

Menetapkan/mengimplementasikan

perencanaan, (5) Menilai perencanaan,

Menilai hasil pemecahan.

Mayer mengungkapkan bahwa terdapat tiga karakteristik pemecahan masalah, yaitu: (1) pemecahan masalah merupakan aktivitas kognitif, tetapi dipengaruhi oleh perilaku, (2) hasil-hasil pemecahan masalah dapat dilihat dari tindakan/perilaku dalam mencari pemecahan, dan (3) pemecahan masalah merupakan suatu proses tindakan manipulasi dari pengetahuan yang telah dimiliki sebelumnya.

Berdasarkan beberapa uraian pengertian di atas dapat kita simpulkan bahwa pemecahan masalah merupakan cara-cara ataupun usaha yang dilakukan seseorang untuk menyelesaikan masalah berdasarkan pengetahuan yang ada pada dirinya sehingga masalah tersebut tidak lagi menjadi masalah baginya.

Kemampuan pemecahan masalah diukur melalui tes kemampuan pemecahan masalah.Tes kemampuan pemecahan masalah dilakukan dengan soal kemampuan pemecahan masalah yang dirancang sesuai dengan indikator yang ada.Tapi perlu kita ketahui bahwa tidak semua soal matematika yang tergolong ke dalam soal pemecahan masalah.

Sebagaimana telah kita ketahui, Matematika Realistik menekankan kepada konstruksi dari konteks benda-benda konkrit sebagai titik awal bagi siswa guna memperoleh konsep matematika. Benda-benda konkret dan obyek-obyek lingkungan sekitar dapat digunakan sebagai konteks pembelajaran matematika dalam membangun keterkaitan matematika melalui interaksi sosial. Benda-benda konkrit dimanipulasi oleh siswa dalam kerangka menunjang usaha siswa dalam proses matematisasi konkret ke abstrak. Siswa perlu 
diberi kesempatan agar dapat mengkontruksi dan menghasilkan matematika dengan cara dan bahasa mereka sendiri. Diperlukan kegiatan refleksi terhadap aktivitas sosial sehingga dapat terjadi pemaduan dan penguatan hubungan antar pokok bahasandalam struktur pemahaman matematika.

Menurut Hans Freudental dalam Sugiman (2007) matematika merupakan aktivitas insani (human activities) dan harus dikaitkan dengan realitas. Dengan demikian ketika siswa melakukan kegiatan belajar matematika maka dalam dirinya terjadi proses matematisasi. Terdapat dua macam matematisasi, yaitu: (1) matematisasi horizontal dan (2) matematisasi vertikal. Matematisasi horisontal berproses dari dunia nyata ke dalam simbol-simbol matematika. Proses terjadi pada siswa ketika ia dihadapkan pada problematika kehidupan / situasi nyata. Sedangkan matematisasi vertikal merupakan proses yang terjadi di dalam sistem matematika itu sendiri; misalnya: penemuan strategi menyelesaiakn soal, mengkaitkan hubungan antar konsep-konsep matematis atau menerapkan rumus/temuan rumus.

Pendidikan Matematika Realistik Indonesia (PMRI) adalah pendidikan matematika sebagai hasil adaptasi dari Realistic Mathematics Education yang telah diselaraskan dengan kondisi budaya, geografi, dan kehidupan masyarakat Indonesia. Dalam Pendidikan Matematika Realistik lebih dipentingkan potensi anak atau siswa yang harus dikembangkan.

Ada beberapa prinsip yang merupakan dasar teoretis PMRI, yaitu:

a) Guided Reinvention dan Progressive Mathematization Prinsip

Guided Reinvention ialah penekanan pada "penemuan kembali" secara terbimbing. Jadi pembelajaran tidak diawali dengan pemberitahuan tentang "ketentuan" atau "pengertian", atau "nama objek matematis" (definisi), atau "sifat"(teorema), atau "aturan", yang diikuti dengan contohcontoh serta penerapannya, tetapi justru dimulai dengan masalah kontekstual yang realistik (dapat dipahami atau dibayangkan oleh siswa, karena diambil dari dunia siswa atau dari pengalaman siswa). Selanjutnya melalui aktivitas diharapkan siswa dapat menemukan kembali pengertian (definisi), sifat-sifat matematis (teorema), dll. Meskipun dalam pengungkapannya masih dalam bahasa informal (nonmatematis).

Prinsip Progressive Mathematization menekankan "matematisasi" atau "pematematikaan", yang dapat diartikan sebagai upaya mengarah ke pemikiran matematis. Dikatakan progresif karena terdiri atas dua langkah yang berurutan, yaitu (1) matematisasi horizontal yaitu berawal dari masalah kontekstual dan berakhir pada matematika yang formal, dan (2) matematisasi vertical yaitu dari matematika formal ke matematika formal yang lebih luas, lebih tinggi, atau lebih rumit.

b) Didactical Phenomenology

Prinsip ini menekankan pembelajaran yang bersifat mendidik dan menekankan pentingnya masalah kontekstual untuk memperkenalkan topik-topik matematika kepada siswa. Tujuan utama pembelajaran dalam PMR bukanlah diketahuinya beberapa konsep atau rumus, atau dikerjakannya banyak soal oleh siswa, melainkan pengalaman belajar yang bermakna atau proses belajar yang bermakna, dan sikap positif terhadap matematika sebagai dampak dari matematisasi, baik horizontal maupun vertikal, kebiasaan berdiskusi dan merefleksi.

c) Self-Developed Model (Membangun sendiri model)

Prinsip ini menunjukkan adanya "jembatan" yang berupa model karena berpangkal pada masalah kontekstual dan akan menuju ke matematika formal. Siswa memiliki kebebasan untuk mengembangkan model sendiri. Model itu mungkin masih sederhana dan masih mirip masalah kontekstualnya atau masih matematika informal (model of), selanjutnya mungkin melalui generalisasi atau formalisasi dapat mengembangkan model yang lebih umum yang mengarah ke matematika formal (model for).

Pendidikan Matematika Realistik memiliki lima dasar aplikatif yang sekaligus merupakan karakteristiknya. Kelima karakteristik Pendidikan Matematika Realistik tersebut yaitu (1) menggunakan konteks, (2) menggunakan 
model, (3) menggunakan kontribusi siswa, (4) menggunakan format interaktivitas, dan (5) Intertwinning (memanfaatkan keterkaitan).

Fungsi tidak hanya sebatas teori yang wajib dipelajari oleh siswa, akan tetapi fungsi adalah aktivitas sehari-hari. Pada umumnya fungsi dikenal sebagai materi yang sulit karena bersifat abstrak dan siswa masih mengalami kesulitan dalam mengkomunikasikan informasi ke dalam bentuk notasi fungsi.

Maka dari itu, salah satu cara mengatasi permasalahan tersebut adalah dengan menggunakan pendekatan pembelajaran Pendidikan Matematika Realistik Indonesia (PMRI)

\section{METODE}

\section{Jenis Penelitian}

Penelitian ini merupakan penelitian deskriptif dengan menggunakan pendekatan kualitatif karena menggunakan data kualitatif yang dideskripsikan untuk menghasilkan gambaran yang mendalam serta terperinci mengenai metakognisi yang digunakan siswa dalam menyelesaikan soal sistem persamaan linear dua variabel.

Keabsahan data dalam penelitian ini menggunakan triangulasi metode karena penelitian ini melakukan pembandingan data dari sumber yang sama menggunakan cara yang berbeda yaitu tes, wawancara, dan dokumentasi untuk menghasilkan data yang sama.

\section{Teknik Pengumpulan Data}

Dalam penelitian ini, metode yang digunakan dalam pengambilan data adalah sebagai berikut:

1. Tes,

Tes adalah sederetan pertanyaan atau latihan atau alat yang digunakan untuk mengukur intelegensi, kemampuan atau bakat yang dimiliki individu atau kelompok.

2. Dokumentasi.

Dokumentasi berasal dari kata dokumen yang berarti tertulis, di dalam melaksanakan metode dokumentasi, penelitian menyelidiki benda-benda tertulis seperti buku-buku, majalah, dokumen peraturan-peraturan, jawaban siswa, notulen rapat, dan sebagainya.

\section{Teknik Analisis Data}

Terdapat tiga teknik analisis data kualitatif yaitu:

1. Reduksi Data

Reduksi data adalah bentuk analisis yang menajamkan, menggolongkan, mengarahkan, membuang yang tidak perlu dan mengorganisasi data sedemikian rupa sehingga kesimpulan akhir dapat diambil.

2. Penyajian Data

Penyajian data adalah kegiatan ketika sekumpulan informasi disusun, sehingga memberi kemungkinan akan adanya penarikan kesimpulan. Bentuk penyajian data kualitatif berupa teks naratif, matriks, grafik, jaringan dan bagan.

3. Penarikan Kesimpulan

Penarikan kesimpulan adalah hasil analisis yang dapat digunakan untuk mengambil suatu tindakan.

\section{Tempat dan Subjek Penelitian}

Tempat penelitian ini dilaksanakan adalah di SMPK St. Paulus Karuni, dan subjek dalam penelitian ini adalah siswa SMPK St. Paulus Karuni kelas VIII A.

\section{HASIL DAN PEMBAHASAN}

Siswa yang mengikuti tes pada berjumlah 10 orang. Peneliti mengkategorikan ke dalam 5 jenis jawaban yang berbeda. Pengkategorian ini berdasarkan perbedaan langkah penyelesaian dan jawaban. Untuk jenis jawaban yang pertama terdapat 3 siswa yang memiliki jawaban serupa, jenis jawaban yang kedua terdapat 4 siswa yang memiliki jawaban serupa, jenis jawaban siswa yang ketiga, keempat dan kelima masing-masing terdiri dari 1 siswa.

Analisis kemampuan pemecahan masalah siswa pada bagian ini adalah hasil tes siswa dengan menggunakan indikator NCTM. Sebelumnya telah dijelaskan bahwa ada terdapat 5 indikator NCTM. Menurut peneliti indikator yang keempat dan kelima memiliki kesamaan tujuan, akan tetapi indikator yang keempat lebih spesifik. Sehingga indikator yang digunakan untuk mengukur kemampuan pemecahan masalah siswa adalah empat indikator pertama. Adapun indikator NCTM yang digunakan yaitu: 1) Siswa dapat mengidentifikasi unsur-unsur yang diketahui, yang ditanyakan, dan kecukupan 
unsur yang diperlukan. 2) Siswa dapat merumuskan masalah matematik atau menyusun model matematik. 3) Siswa dapat menerapkan strategi untuk menyelesaikan berbagai masalah (sejenis dan masalah baru) dalam atau di luar matematika. 4) Siswa dapat menjelaskan hasil sesuai permasalahan asal.

Berikut soal yang diberikan.

Seli dan Meci pergi ke toko buku untuk membeli buku tulis. Seli membeli 5 buku tulis seharga Rp 7.500 dan Meci membeli 2 buku tulis seharga Rp 3.000. Jika Tio juga membeli buku yang sama sebanyak 8 buah buku, maka berapa jumlah uang yang harus ia bayar?

Berdasarkan Didactical Phenomenology yaitu prinsip yang menekankan pembelajaran bersifat mendidik dan menekankan pentingnya masalah kontekstual untuk memperkenalkan topik-topik matematika kepada siswa. Tujuan utama pembelajaran dalam PMR bukanlah diketahuinya beberapa konsep atau rumus, atau dikerjakannya banyak soal oleh siswa, melainkan pengalaman belajar yang bermakna atau proses belajar yang bermakna, dan sikap positif terhadap matematika sebagai dampak dari matematisasi, baik horizontal maupun vertikal, kebiasaan berdiskusi dan merefleksi. Soal ini dirancang berdasarkan masalah kontekstual dan sebelumnya siswa telah diajarkan menggunakan model PMR.

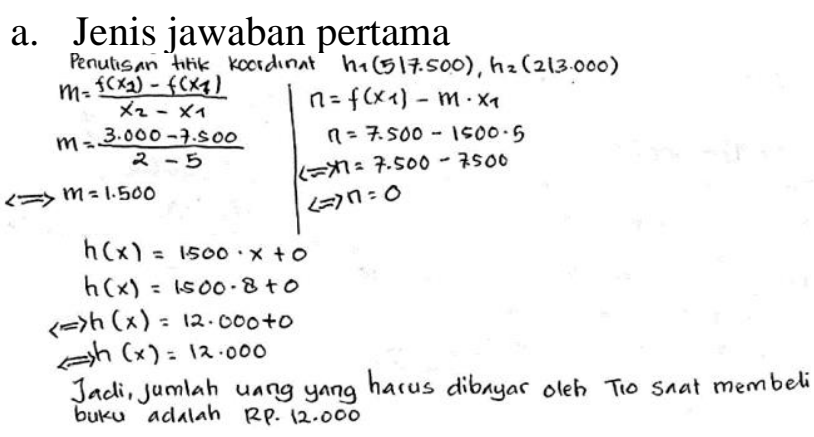

\section{Gambar 1}

Gambar 1 merupaka jenis jawaban yang pertama terdiri dari tiga siswa. Siswa ini menterjemahkan kalimat kedua dari soal dalam bentuk koordinat titik. Yaitu pembelian Seli ke dalam bentuk koordinat titik $\boldsymbol{h}_{\mathbf{1}}$ dan pembelian Meci dalam koordinat titik $\boldsymbol{h}_{\mathbf{2}}$. Pada langkah kerja siswa, terdapat kalimat "Jumlah uang yang harus dibayar oleh Tio saat membeli buku adalah". Ini berarti, siswa memahami bahwa yang ditanyakan adalah Jumlah uang yang harus dibayar oleh Tio. Berdasarkan koordinat titik yang sudah dibuat, siswa menggunakan rumus yang sudah dipelajarinya untuk menentukan gradien $m$. Siswa memisalkan untuk jumlah buku yang dibeli Seli dengan $\boldsymbol{x}_{\mathbf{1}}$ dan jumlah uang yang dibayarnya sebagai $\boldsymbol{f}\left(\boldsymbol{x}_{\mathbf{1}}\right)$, kemudian jumlah buku yang dibeli oleh Meci dengan $\boldsymbol{x}_{2}$ dan uang yang dibayarnya sebagai $\boldsymbol{f}\left(\boldsymbol{x}_{\mathbf{2}}\right)$. Pada bagian ini juga siswa menggunakan rumus yang sudah dipelajarinya untuk menentukan nilai konstanta $n$ (titik di mana grafik memotong sumbu $y$ ) berdasarkan $\boldsymbol{x}_{\mathbf{1}}$ dan $\boldsymbol{f}\left(\boldsymbol{x}_{\mathbf{1}}\right)$ serta nilai $\boldsymbol{m}$ yang sudah diperoleh. Setelah menentukan nilai $m$ dan $n$, siswa membuat model matematika berupa persamaan fungsi untuk menghitung jumlah uang yang harus dibayar oleh Tio. Siswa memisalkan "berapa pun jumlah buku yang dibeli" dengan variabel $x$. Siswa mensubstitusikan nilai dari $\boldsymbol{x}$ kemudian siswa menghitung persamaan fungsi berdasarkan operasi-operasi yang digunakan untuk memperoleh suatu nilai fungsi. Siswa membuat kesimpulan bahwa berdasar nilai fungsi yang diperoleh, merupakan jumlah uang yang harus dibayar oleh Tio.

Berdasarkan hasil deskripsi di atas dapat disimpulkan bahwa siswa tersebut memenuhi keempat indikator NCTM.

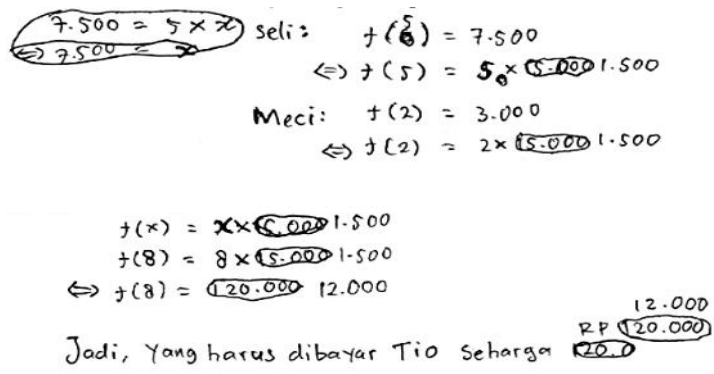

b. Jenis jawaban kedua

\section{Gambar 2}

Gambar 2 menunjukkan bahwa siswa menterjemahkan kalimat kedua ke dalam bentuk fungsi. Yaitu, pembelian Seli ke dalam bentuk fungsi $f(5)=7.500$ dan pembelian Meci ke dalam bentuk fungsi $f(2)=3.000$. Pada langkah kerja siswa, terdapat kalimat "Jadi yang harus dibayar Tio seharga ". Ini berarti, siswa memahami bahwa yang ditanyakan adalah Jumlah uang yang harus dibayar oleh Tio. Berdasarkan unsur-unsur yang telah diketahui, siswa mengubah jumlah uang yang dibayar oleh Seli ke dalam bentuk penulisan yang berbeda 
yaitu $5 \times 1.500$ dan jumlah uang yang dibayar oleh Meci ke dalam bentuk $2 \times 1.500$. Dari kedua bentuk penulisan tersebut, siswa membentuk model matematika secara umum. Siswa memisalkan jumlah buku yang dibeli dengan variabel $\mathrm{x}$ yang dikalikan dengan harga satu buah buku. Siswa mensubstitusikan variabel $\mathrm{x}$ dengan banyaknya buku yang dibeli oleh Tio. Kemudian menghitung persamaan berdasarkan operasi-operasi yang digunakan untuk memperoleh nilai fungsi. Siswa membuat kesimpulan bahwa nilai fungsi yang telah diperoleh adalah banyaknya uang yang harus dibayar oleh Tio.

Berdasarkan hasil deskripsi di atas dapat disimpulkan bahwa siswa tersebut memenuhi keempat indikator NCTM.

c. Jenis jawaban ketiga

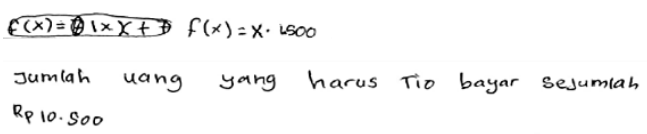

Gambar 3

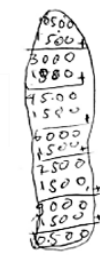

Gambar 3 menunjukkan bahwa siswa mengidentifikasi unsur-unsur yang diketahui. Hal itu ditunjukkan siswa ketika siswa mencoba menghitung dan berhenti pada perhitungan ketujuh. Yaitu siswa banyaknya buku yang dibeli oleh Seli dijumlahkan dengan banyaknya buku yang dibeli oleh Meci. Pada langkah kerja siswa, terdapat kalimat "Jumlah uang yang harus Tio bayar sejumlah". Ini berarti, siswa memahami bahwa yang ditanyakan adalah Jumlah uang yang harus dibayar oleh Tio. Berdasarkan perhitungan tersebut siswa membuat model matematika atau bentuk umum dari fungsi tersebut. Berdasarkan model tersebut siswa tidak dapat menerapkan strategi yang sudah dibuatnya untuk menyelesaikan masalah. Seharusnya siswa hanya menggantikan variabel $\mathrm{x}$ dengan banyaknya buku yang dibeli oleh Tio. Namun siswa menggunakan strategi yang berbeda untuk memperoleh jumlah uang yang harus dibayar oleh Tio, yaitu siswa menjumlahkan 1.500 sebanyak tujuh kali dan mendapatkan hasil 10.500. Berdasarkan hasil cakaran, siswa menarik kesimpulan banyaknya uang yang harus dibayar oleh Tio.
Berdasarkan hasil deskripsi di atas dapat disimpulkan bahwa siswa tersebut memenuhi indikator yang pertama dan kedua dari NCTM.

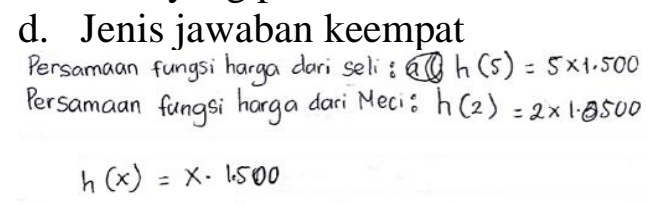

Menurut saya, jumlah uang yang harus dibayar oleh Tio adalah Rp. 12.000. Karena, Tio membeli 8 buah buku dan harga 1 buku adalah Rp. 1500 kemudian saya kalikan 8 dengan 1.500 saya mendapatkan hasil 12.000. Saya juga melihat persamoan mendapatkan hasil 12.000. Saya juga melihat persamaan dian saya kalikan dengan 1.500 saya mendapatkan hasil 12.000

\section{Gambar 4}

Gambar 4 menunjukkan siswa ini menterjemahkan kalimat kedua dari soal dalam bentuk persamaan fungsi yaitu: Harga yang dibayar Seli dari 5 buah buku yaitu Rp.7.500, siswa mengubah dalam bentuk penulisan yang berbeda menjadi $5 \times 1.500$ sehingga persamaan fungsi yang diperoleh adalah $h(5)=5 \times 1.500$. Harga yang dibayar Meci dari 5 buah buku yaitu Rp.3.000, siswa mengubah dalam bentuk penulisan yang berbeda menjadi $2 \times 1.500$ sehingga persamaan fungsi yang diperoleh adalah $h(2)=2 \times 1.500$. Pada langkah kerja siswa, terdapat kalimat "menurut saya, jumlah uang yang harus dibayat oleh Tio adalah". Ini berarti, siswa memahami bahwa yang ditanyakan adalah Jumlah uang yang harus dibayar oleh Tio. Berdasarkan harga yang dibayar oleh Seli dan Meci dalam bentuk penulisan yang berbeda, siswa membuat model secara umum yaitu dengan memisalkan jumlah buku yang dibeli dengan variabel $x$. Selanjutnya siswa menerapkan model matematika yang telah dibuat. Hanya saja siswa menjelaskan dengan kata-kata. Siswa juga menggantikan variabel $x$ dengaan jumlah buku yang dibeli oleh Tio dan menghitung hasilnya. Siswa membuat kesimpulan, berdasar nilai fungsi yang dihitungnya merupakan jumlah uang yang harus dibayar oleh Tio.

Berdasarkan hasil deskripsi di atas dapat disimpulkan bahwa siswa tersebut memenuhi keempat indikator NCTM.

e. Jenis jawaban kelima 


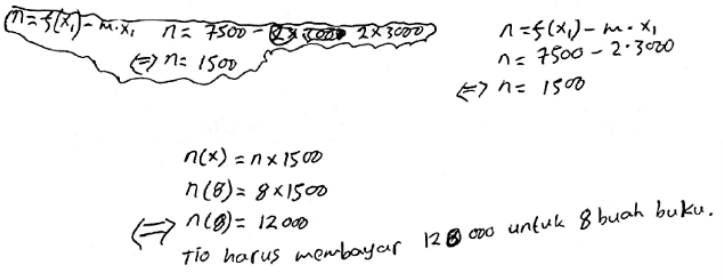

Gambar 5

Gambar 5 menunjukkan bahwa siswa menerapkan beberapa bilangan yang terdapat pada soal ke dalam sebuah rumusan. Berdasarkan langkah-langkah kerja siswa, terdapat kalimat "Tio harus membayar 12.000 untuk 8 buah buku". Ini terlihat bahwa yang dipahami siswa mengenai yang ditanyakan adalah jumlah uang yang harus dibayar Tio. Pada bagian ini, siswa menuliskan model matematik yaitu $n=$ $f\left(x_{1}\right)-m \times x_{1}$. Kemudian siswa mensubstitusikan nilai dari $f\left(x_{1}\right), x_{1}$ dan $m$ yaitu $f\left(x_{1}\right)$ dengan $7.500, x_{1}$ dengan 3.000 dan $m$ dengan 2. Dari pekerjaannya siswa dapat dilihat bahwa siswa melakukan kesalahan mensubstitusikan nilai dari $x_{1}$ dan $m$. Jika nilai $f\left(x_{1}\right)$ yaitu 7500 maka otomatis yang menjadi $x_{1}$ yaitu 5. Dan seharusnya disini siswa harus menentukan nilai $m$.

Dari nilai $\mathrm{n}$ yang sudah diperoleh, siswa membentuk model $n(x)=n \times 1500$. Model ini salah karena tidak menggunakan variabel dengan tepat. Langkah yang digunakan untuk menemukan model juga salah. Hanya saja siswa menemukan nilai $n=1.500$ secara kebetulan. Siswa mensubstitusikan variabel $\mathrm{n}$ dan $\mathrm{x}$ dengan 8. Kemudian siswa menghitung fungsi tersebut berdaarkan operasi yang digunakan. Siswa membuat kesimpulan berdasar nilai fungsi yang dihitungnya merupakan jumlah uang yang harus dibayar oleh Tio.

Berdasarkan hasil deskripsi di atas dapat disimpulkan bahwa siswa tersebut memenuhi indikator yang pertama, ketiga dan keempat dari NCTM.

\section{KESIMPULAN}

Pada pembelajaran sebelumnya siswa telah dibimbing dan diajarkan untuk menemukan sebuah rumus atau model umum matematika berdasarkan unsur-unsur yang diketahui dari soal. Hal ini sesuai dengan Prinsip Guided Reinvention yaitu penekanan pada "penemuan kembali" secara terbimbing. Jadi pembelajaran tidak diawali dengan pemberitahuan tentang "ketentuan" atau "pengertian", atau "nama objek matematis" (definisi), atau "sifat"(teorema), atau "aturan", yang diikuti dengan contoh-contoh serta penerapannya, tetapi justru dimulai dengan masalah kontekstual yang realistik (dapat dipahami atau dibayangkan oleh siswa, karena diambil dari dunia siswa atau dari pengalaman siswa). Selanjutnya melalui aktivitas diharapkan siswa dapat menemukan kembali pengertian (definisi), sifat-sifat matematis (teorema), dll. Meskipun dalam pengungkapannya masih dalam bahasa informal (nonmatematis). Selanjutnya Self-Developed Model (Membangun sendiri model) yaitu berdasarkan model yang dibuat masih kontekstual siswa menjeneralisasikan ke dalam bentuk umum.

Berdasarkan hasil deskripsi yang telah dijabarkan di atas terdapat Tujuh siswa dengan jenis jawaban yang pertama, kedua dan keempat memenuhi empat indikator. Satu siswa dengan jenis jawaban yang ketiga hanya mencapai dua indikator yaitu indikator pertama dan kedua, dan satu siswa dengan jenis jawaban yang kelima memenuhi tiga indikator yaitu indikator yang pertama, ketiga dan keempat. Atau dengan kata lain terdapat $8(80 \%)$ siswa memenuhi keempat indikator dari NCTM, 1 (10\%) siswa tidak memenuhi indikator ketiga dan keempat dan 1 (10\%) siswa tidak memenuhi indikator kedua.

Berdasarkan hasil deskripsi dan penjabaran di atas maka disimpulkan bahwa siswa tersebut memiliki kemampuan pemecahan masalah matematika pada materi fungsi dengan baik.

\section{DAFTAR PUSTAKA}

Ahmad Fauzan. (2003). Rute Belajar dalam RME: Suatu Arah untuk Pembelajaran Matematika. Makalah, disampaikan pada Seminar Nasional Pendidikan Matematika di Universitas Sanata Dharma Yogyakarta 27-28 Maret 2003.

Mayer, R. E (1992), Thinking, Problemsolving, Cognition, 2nded. New York,NY: Freeman https://media.neliti.com/media/publication s/176876-ID-perilaku-metakognisi-siswadalam-pemecah.pdf

NCTM. (2000). Principles and Standards for School Mathematics. United States of America : The National Council of 
Teachers of Mathematics,

Inc.https://media.neliti.com/media/publica tions/217237-pemecahan-masalahmatematis-siswa-ditinj.pdf

Nyimas Aisyah dkk, (2012), Pengembangan Pembelajaran Matematika, h.147 http://repository.uinsu.ac.id/5032/4/BAB \%20II.pdf

Solso, L. Robert, Otto H. Maclin dan M. Kimberly Machlin. 2007. Psikologi Kognitif Edisi Ke Delapan. Jakarta: Erlangga.

Suherman, Ermandkk. 2003. Strategi Pembelajaran Matematika Kontemporer. Bandung: PT Remaja Rosdakarya.

Marpaung, Y. (2003). Perubahan Paradigma Pembelajaran Matematika di Sekolah (makalah) 